\title{
Author Correction: Genetic and regulatory mechanism of susceptibility to high-hyperdiploid acute lymphoblastic leukaemia at 10q21.2
}

\author{
James B. Studd, Jayaram Vijayakrishnan, Minjun Yang, Gabriele Migliorini, Kajsa Paulsson \& Richard S. Houlston
}

Nature Communications 8:14616 doi: 10.1038/ncomms14616 (2017); Published online 3 Mar 2017; Updated 25 May 2018

The original version of this Article contained an error in the title, the final paragraph of the Introduction and the first subsection of the Results, where chromosome locus 10q21.2 was incorrectly referred to as 10p21.2. This has now been corrected in both the PDF and HTML versions of the Article.

(c) Open Access This article is licensed under a Creative Commons Attribution 4.0 International License, which permits use, sharing, adaptation, distribution and reproduction in any medium or format, as long as you give appropriate credit to the original author(s) and the source, provide a link to the Creative Commons license, and indicate if changes were made. The images or other third party material in this article are included in the article's Creative Commons license, unless indicated otherwise in

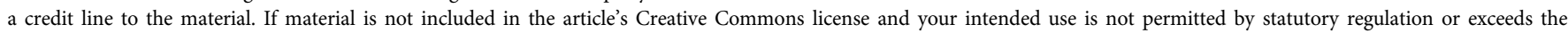
permitted use, you will need to obtain permission directly from the copyright holder. To view a copy of this license, visit http://creativecommons.org/licenses/by/4.0/

(C) The Author(s) 2018 